\title{
ЗООЛОГИЯ
}

УДК 902/7.042

\section{BONES FROM THE WOODEN STREET PAVEMENTS OF THE MEDIEVAL NOVGOROD THE GREAT: CAN THEY TELL A STORY?}

\author{
A.V. Zinoviev \\ Tver State University, Tver
}

\begin{abstract}
Here I discuss a collection of animal bones, found on the two succeeding wooden pavements of the medieval Kozmodemyanskaya Street of Novgorod the Great. The pioneering study draws attention to the bones found in wooden street pavements as a valuable source of information on the life of the medieval city.
\end{abstract}

Keywords: zooarchaeology, medieval Novgorod the Great, wooden street pavements, bones, composition, accumulation, dogs.

DOI: $10.26456 /$ vtbio98

Introduction. Osteological materials from archaeological excavations are a valuable source of information on the history of humankind. Frequently, they add the knowledge missing in the written sources. Collected in different areas of human settlements bones often characterize their habitual use. One of such areas in the medieval Russian are so-called wooden street pavements, built to make the firm ground on otherwise muddy streets. Medieval Novgorod the Great is especially famous for its wooden pavements. The maximal number of preserved succeeding layers of wooden street pavements build one on the top of the other is 28 (Yanin, 1965). Besides dendrochronological information, wooden pavements yield an array of artifacts. And if various human-made artifacts, such as coins, bracelets, wooden and bone tools, etc. are relatively welldescribed (Yanin, 1992), information on bones other then tools or decorations is largely missing. Only bones used to create the so-called bone pavements of Novgorod the Great, Pskov and Moscow are treated in detail (Strokov, Bogusevich, 1939; Artzikhovsky, 1949; Grozdilov, 1962; Yavorskaya, 2013) (Fig. 1). Some of such pavements were still existing in Moscow downtown at the end of the 19th cent. (Scherbo, 1991). The situation described is also true for West European cities, where wooden pavements were discovered (Schofield, Vince, 2003). The study which I present here is thus the first of its kind in the European archaeology. It is aimed to describe and analyze the ordinary bones deposited or lost on the top or beneath the short distance of the two succeeding wooden street pavement in the medieval Novgorod the Great. This adds to the 
reconstruction of "complex and very winding paths of movement of bones in urban space" (Yavorskaya, Antipina, 2017).

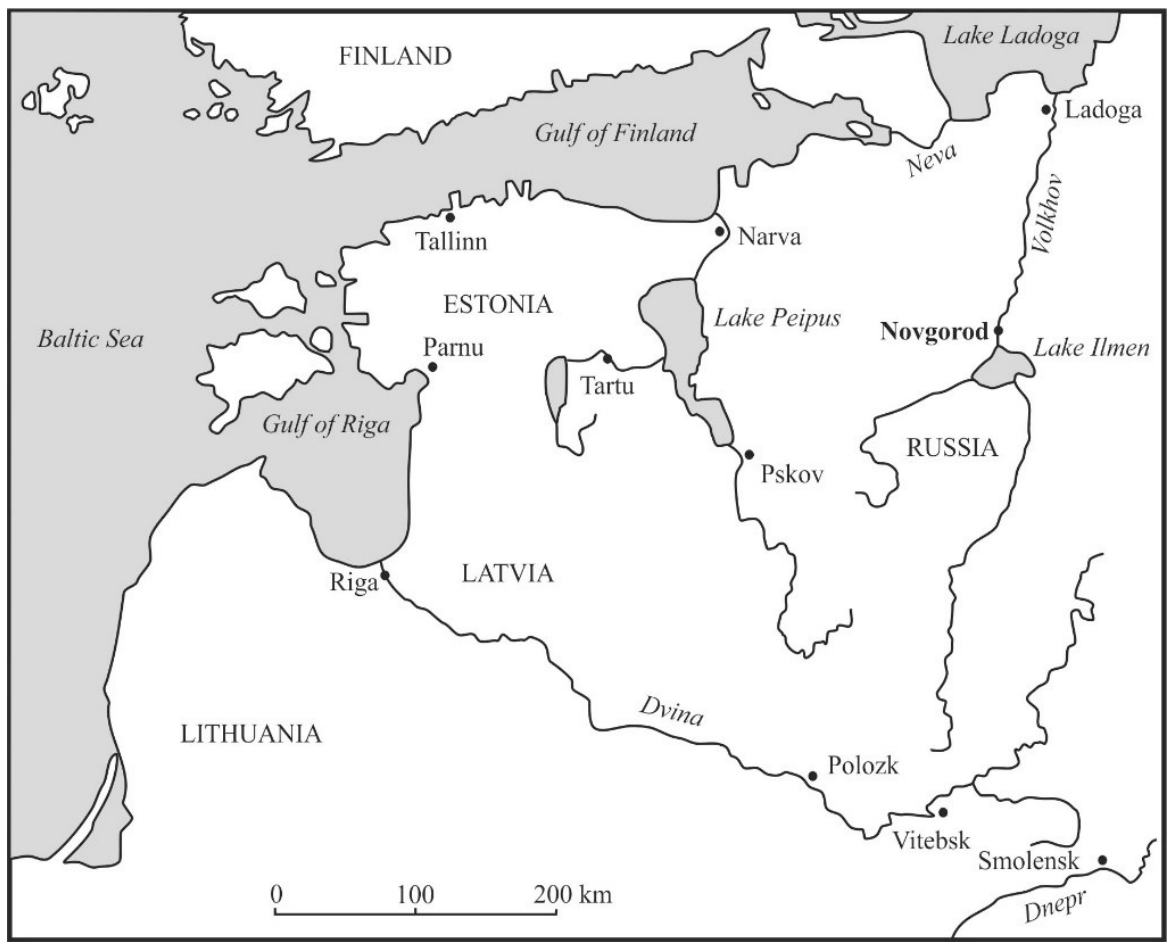

Fig. 1. Map showing the location of Novgorod and Pskov.

Рис. 1. Карта, указывающая положение Новгорода Великого и Пскова.

Material and Methods. 57 animal bones from 45 individuals of 5 species of domestic animals (Table 1) were analyzed. Bones were collected from the two lowest and better preserved (numbered as IV and V) 18-meters long succeeding wooden pavements of the historical Kozmodemyanskaya Street (Kozmodemyanskaya-4 Excavation Site) (Fig. 2). Both pavements are preliminarily dated by the second half of 14th cent. Remains of at least five wooden city manors contemporaneous to the wooden pavements were unearthed. Besides bones, the excavations yielded: birchbark utensils, sinkstones, the glass bead, iron knives, the iron spearhead, the stone spindle and the lead seal (Oleynikov OM, pers. comm).

The withers height of a dog was calculated using 'Harcourt factors' (Harcourt, 1974).

Results. The number of animal bones and minimal numbers of individuals are indicated in Table 1.

Cattle (Bos taurus). 29 bones and their fragments, originating from approximately 22 individuals, are represented at the excavation site. Fragments of the ribs and tubular bones of the extremities, bearing cuts and 
traces of gnawing, dominate. The absence of whole tubular bones made it impossible to estimate precise withers heights of individuals. However, the comparison of fragments with whole bones of animals from other simultaneous layers of Novgorod the Great reveal the remains as belonging of the small unconsciously selected breed Bos taurus brachyceros (Fig. 3A) that was common in the Middle Ages throughout the forest zone of European Russia (Tsalkin, 1970; Zinoviev, 2015).

Table 1

Bone counts by wooden street pavements (IV and V) and MNI from Kozmodemyanskaya Street

Кости животных с деревянных мостовых (IV и V) Козьмодемьянской улицы и минимальное количество особей, которым они принадлежали

\begin{tabular}{|l|c|c|c|c|}
\hline Animals & IV & V & Total number & MNI \\
\hline Cattle & 1 & 28 & 29 & 22 \\
\hline Pig & 2 & 16 & 18 & 16 \\
\hline Horse & 0 & 4 & 4 & 2 \\
\hline Dog & 1 & 3 & 4 & 3 \\
\hline Goat/Ship & 1 & 1 & 2 & 2 \\
\hline TOTAL & 5 & 52 & 57 & 45 \\
\hline
\end{tabular}

MNI - minimal number of individuals

МНО - минимальное количество особей

Pig (Sus scrofa domesticus) is represented by the second largest number of bones in the sample: 18 fragments belonging to approximately 16 individuals (Table 1). Fragments of the tubular bones of the limbs and lower jaw are dominant (Fig. 3B). Almost all bones carry marks of cutting and gnawing. Most of the bones come from young males up to 2.5-3.0 years old.

Horse (Equus caballus) bones are represented by 4 fragments derived from two animals. Two cervical vertebrae, the humerus (see Fig. 3C) and the tarsus bones do not bear traces of kitchen processing. However, they show dog bites. Fused naviculare and cuboideum (Fig. 3D), age-related changes on the humerus and cervical vertebrae characterize horses, the bones of which were found on wooden pavements, as aged animals. A comparative analysis shows that the remains under discussion belong to small and medium-sized horses according to the classification by Vitt (1952).

Dog (Canis familiaris) is also represented by four bones. They belong to three individuals. Two branches of the lower jaw come from dogs 6-8 years old (see Figure 3E); one belongs to a relatively young individual of 2-3 years of age. The humerus belonging to an adult individual, allowed to calculate its withers height, which was $52,9 \pm 0,9 \mathrm{~cm}$. 


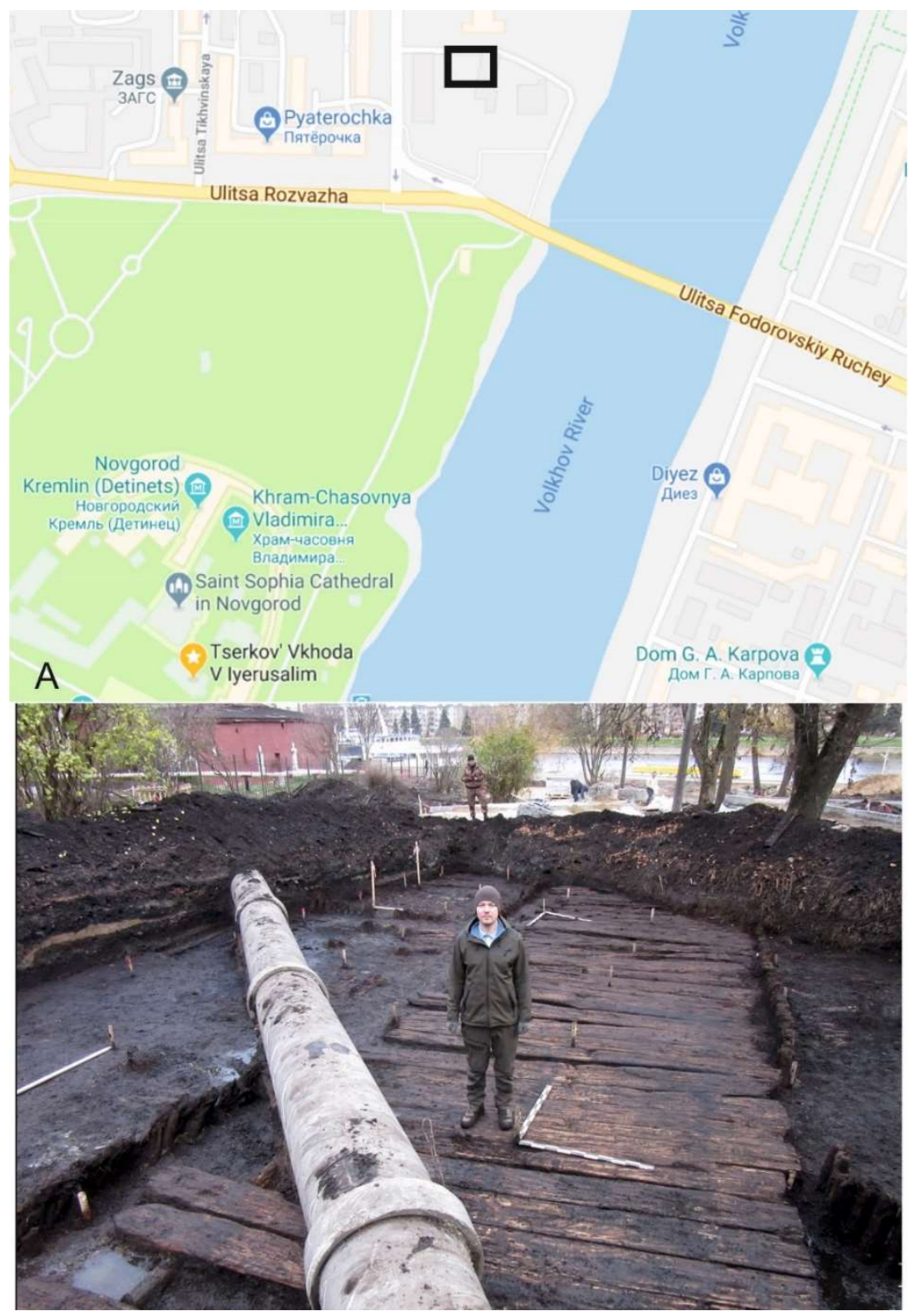

Fig. 2. Kozmodemyansky-4 Excavation Site on (A) the Google Map of Novgorod the Great, and (B) on the photograph showing the lowest and the best-preserved wooden street pavement $\mathrm{V}$, built of wooden planks up to $40 \mathrm{~cm}$ wide. View from the north-west. The photograph is courtesy of Isaev AA, Gaidukov PG, and Oleynikov OM.

Рис. 2. Раскоп Козьмодемьянская-4 (A), нанесенный на Google Карты и (Б) фотография, показывающая нижнюю и лучше всего сохранившуюся деревянную мостовую $\mathrm{V}$, составленную из деревянных плах до 40 см шириной. Вид с северо-запада. Фотография любезно предоставлена Исаевым А.А., Гайдуковым П.Г. и Олейниковым О.М. 


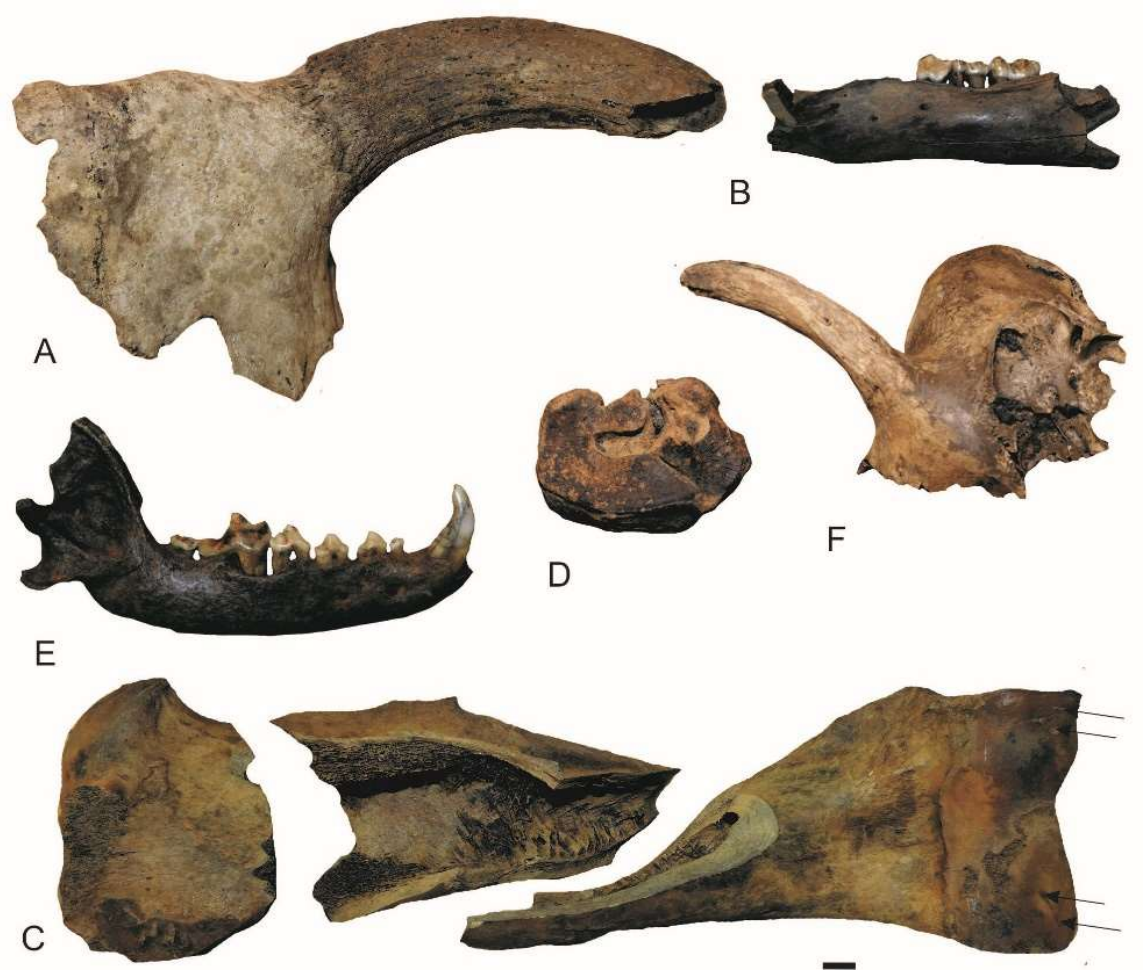

Fig. 3. Some bones of domestic animals from the Kozmodemyansky-4 Excavation Site: (A) fragment of the left frontal bone with a horn core of Bos taurus

brachyceros, (B) fragment of the left mandibular branch of the male pig of 2.5-3.5 years old, (C) fragments of the left humerus of an adult horse with canine toothmarks (arrows), (D) fused left naviculare and cuboideum of an aged horse, (E) right mandibular branch of the 6-8 years old dog (note the alveolar bone destruction due to the inflammation of the parodont), (F) skull fragment with a horn core of a young goat. The scale bar is $1 \mathrm{~cm}$.

Рис. 3. Некоторые кости домашних животных из раскопа Козьмодемьянская4: (А) фрагмент левой лобной кости с костным основанием рога Bos taurus brachyceros, (Б) фрагмент левой ветви нижней челюсти самца свиньи 2.5-3.5летнего возраста, (В) фрагмент левой плечевой кости взрослой лошади со следами собачьих зубов (стрелки), (Г) слившиеся левые naviculare и cuboideum взрослой лошади, (Д) правая ветвь нижней челюсти 6-8-летней собаки (обратите внимание на резорбцию альвеолярной кости в результате воспаления пародонта), (Е) фрагмент черепа с костным основанием рога молодого козла. Масштабная линейка $-1 \mathrm{~cm}$.

Goat/Sheep (Capra hircus/Ovis aries) are represented by two fragments. The part of the skull with a horn core belongs to a young goat (Fig. 3F). Another fragment is a piece of rib with traces of kitchen processing. 
Discussion. The analysis of the remains of animals found on the two succeeding wooden pavements of the medieval Kozmodemyanskaya Street of Novgorod the Great yields two important traits. The first trait is relatbed to the nature of the bones. It is in good agreement with original and literary data on the quantitative composition, constitutional and age characteristics, as well as the way of the use of domestic animals in medieval Novgorod the Great (see review in Zinoviev, 2009). The leading positions hold cattle and pig, the bone remains of which are of kitchen origin. In both cases, the remains of young animals in the appropriate age for slaughter dominate, with a relatively large number of pig's jaws, which is consistent with the "meat character" of the pig's head. The medium-sized horse is represented by the remains of "aged animals" that do not bear traces of kitchen processing but have dog bites. Dogs are represented mainly by mature medium-sized animals, falling in the group $(45-64 \mathrm{~cm})$ which was the most widespread in the medieval Novgorod the Great (Zinoviev, 2012). The minimum number of bones and the fragmentary nature of the bones of small ruminants do not allow discussing them in any detail here.

The second trait "tells a story" about the way how the bones got deposited on pavements. In fact, the set of bones and their condition are characterized precisely as "street debris". The high fragmentation of the majority of bones and dog bites indicate the way in which most of the bones got on the pavements. Most likely, these fragments were brought here by dogs, including horse bones' fragments, that do not have kitchen marks but bear canine tooth marks (Fig. 3C). Large chunks of cattle and goat skulls (Fig. 3A, 3F) were deposited in drainage ditches along the sides of pavements. The bone remains of those same dogs are also present. Relatively small, dogs successfully guarded the adjacent manors, attracting attention. At the same time, running freely along the pavement, they did not pose a threat to people, gradually accumulating the bone collection on the two 18-meters long succeeding wooden pavements of the historical Kozmodemyanskaya Street, which became the subject of my research.

Acknowledgments. I would like to thank Dr. Petr Gaidukov and Dr. Oleg Oleynikov of the Institute of Archaeology of the Russian Academy of Sciences (Moscow, Russia), who kindly provided osteological material, pictures, and dating. I state that there is no conflict of interest.

\section{References}

Artzikhovsky A.V. 1949. Excavations of the eastern part of Dvoristche in Novgorod // Materials and Studies on the Archaeology of the USSR. V. 11. P. 152-76 (in Russian).

Grozdilov G.P. 1962. Excavations of an Ancient Pskov // Archaeological Collection of the State Hermitage. V. 4. P. 7-76 (in Russian). 
Harcourt R.A. 1974. The dog in prehistoric and early historic Britain // Journal of Archaeological Science. V. 1. № 2. P. 151-175.

Scherbo G.V. 1991. Wooden pavements of Moscow (XI-XIX centuries) // History and Technology, An International Journal. V. 8. № 2. P. 119-125.

Schofield J., Vince A. 2003. Medieval towns. The archaeology of British towns in their European setting. Leicester: Leicester University Press. Studies in the Archaeology of Medieval Europe. $352 \mathrm{p}$.

Strokov A., Bogusevich V. 1939. Archaeological studies of Novgorod. Novgorod: Acad. Sci. USSR Press (in Russian).

Tsalkin V.I. 1970. The oldest domestic animals of Eastern Europe. Moscow: Nauka (in Russian).

Vitt V.O. 1952. Horses of Pazyryk burial mounds // Soviet Archaeology. V. 16. P. 163-205 (in Russian).

Yanin V.L. 1965. I sent you birchbark. Moscow: Moscow State Univ. Publ. 192 p. (in Russian).

Yanin V.L. 1992. An introduction to Novgorod archaeology // The archaeology of Novgorod, Russia. Lincoln: Society of Medieval Archaeology Monographs. V. 13. P. 1-4.

Yavorskaya L.V. 2013. "Bone pavements" in ancient Russian towns: "anatomy" of one archaeological riddle // Zoologichesky Zhurnal. V. 92. P. 1179-1189 (in Russian, English abstract).

Yavorskaya L.V, Antipina E.E. 2017. Archaeozoological studies in the medieval town: contexts and interpretations / LXII Seminar "Archaeology and History of Pskov and Pskov Region". Pskov Archaeological Centre. Moscow-Pskov: Institute of Archaeology of the Russian Academy of Sciences. P. 358-366 (in Russian).

Zinoviev A.V. 2009. Review of the archaeozoological material obtained from "Desyatinny-1" excavation site of Novgorod the Great in 2008 // Novgorod and Novgorod Region. History and Archaeology. Veliky Novgorod: Novgorod State United Museum. V. 23. P. 189-207 (in Russian).

Zinoviev A.V. 2012. Study of the medieval dogs from Novgorod, Russia (X-XIV century // International Journal of Osteoarchaeology. V. 22 P. 145-157.

Zinoviev A.V. 2015. Review of the stature of cattle and horses from the medieval // Tver Archaeological Collection. V. 10. №. 2. P. 326-330 (in Russian).

\title{
КОСТИ С ДЕРЕВЯННЫХ МОСТОВЫХ СРЕДНЕВЕКОВОГО НОВГОРОДА ВЕЛИКОГО: МОГУТ ЛИ ОНИ РАССКАЗАТЬ ИСТОРИЮ?
}

\author{
А.В. Зиновьев \\ Тверской государственный университет, Тверь
}

В работе обсуждается коллекция костей животных, найденных на двух следующих друг за другом деревянных мостовых средневековой Козьмодемьянской улицы Великого Новгорода. Основанная на 
небольшой материале, работа призвана привлечь внимание к анализу костных останков с мостовых, как ценному источнику информации о жизни средневекового города.

Ключевые слова: зооархеология, средневековый Новгород Великий, деревянные мостовые, кости, набор, скопление, собаки.

\section{Об авторе}

ЗИНОВЬЕВ Андрей Валерьевич - доктор биологических наук, заведующий кафедрой зоологии и физиологии, ФГБОУ ВО «Тверской государственный университет», 170100, Тверь, ул. Желябова, д. 33, email: Zinovev.av@tversu.ru.

Зиновьев А.В. Кости с деревянных мостовых средневекового Новгорода Великого: могут ли они рассказать историю? / А.В. Зиновьев // Вестн. ТвГУ. Сер. Биология и экология. 2019. № 3(55). С. 61-68. 